\title{
A comparison of economic performance in the fisheries sector: A short- and long-term perspective
}

\author{
P. Le Floc' $h^{a, *}$, F. Daurès ${ }^{b}$, C. Brigaudeau ${ }^{a}$ and J. Bihel ${ }^{a}$ \\ ${ }^{a}$ GdR AMURE/CEDEM, Université de Bretagne Occidentale, France \\ ${ }^{\mathrm{b}}$ GdR AMURE/IFREMER, Economic Marine Department, France \\ *: Corresponding author : P. Le Floc'h, email address : plefloch@univ-brest.fr
}

\begin{abstract}
:
Indicators of the economic performance of fishing vessels are frequently computed in various countries. In this paper, we use different types of information to assess capital value and the economic performance of fishing vessels. On the one hand, field surveys provide technical and financial information on the main components of fishing capital. On the other hand, book values are given in bookkeeping databases. We use both sources of information on fishing capital are used for the same set of vessels, namely the commercial fishing fleet of the French region of Brittany. Based on these two sources, measures of economic performance can be produced for the short term using gross surplus; and for the long term including the cost of capital. The measures of performance obtained are presented and the differences between them are then discussed.
\end{abstract}

JEL classification codes: C81; D24; M41; Q22 


\section{Introduction}

Indicators of the economic performance of fishing vessels are frequently computed in various countries. In the European Union, concerted action on the economic assessment of EU fisheries has produced indicators on economic performance of selected European fishing fleets since 1998 [1]. Economic performance is based on revenue, cost, profit, employment and landings composition.

However, indicators can be biased depending on the origin of the individual data, mainly bookkeeping and field surveys [15]. The collection of data used to measure economic and financial performance of the fishing fleets in the European Union is now ruled by Council Regulation No 1543/2000 and Commission Regulation No 1639/2001. Depending on the Member State, economic information is provided by bookkeeping or field survey methods. A comparison of economic and financial indicators estimated from these two methods of collection was made in the French study based on a common sub-sample [4]. The main conclusions showed a good similarity between earnings and various cost categories. However, three categories - labour costs, maintenance \& repairs and miscellaneous costs, displayed substantial gaps.

In the previous paper, economic performance was assessed only in the short-term through landings values, operating costs and gross surplus. At that time, it was not possible to investigate costs such as fixed capital depreciation or financial costs. In this paper we suggest using the extended data from bookkeeping and economic surveys for a common sample. This research is part of an EU-funded project and a national-funded project ${ }^{1}$. We use different types of information to assess capital value and the economic performance of fishing vessels. Firstly, field surveys provide economic information on earnings and operating costs. Then, technical data are collected based on the main components of fishing capital the vessel, engine, electronics and storage equipment. Consequently, capital value is shown directly from surveys through insurance value. Estimated values have been calculated through econometric models based on survey data and series data on the second-hand market. On the other hand, bookkeeping databases provide landings value, operating and financial costs. Bookkeeping data are collected by the Regional Economic Observatory of Fisheries in Brittany, a NGO created by a professional fishers organisation in 1989. Here, capital price is given as book value and the capital costs correspond to specific fiscal regulation adopted in the French Fisheries industry. For this reason large gaps can be observed between both survey and bookkeeping methods with regard to long-term economic performance.

This paper is set out in four sections. Section 2 describes the fishing fleet in Brittany and the common sample from which both economic performance indicators (survey and bookkeeping) are computed. Section 3 presents the economic performance in the short term. Landings value, value-added and gross surplus are compared for the entire common sample and for sub-samples, differentiating boats under and above 12 metres long. Section 4 is devoted to capital valuation methods. Fiscal regime and economic valuation supply the two sides of capital. To a certain degree, both methods can be linked if no exemption is permitted by the national tax laws. As far as the French sample is concerned, a special regime is afforded to the fishing fleets so capital costs show major differences depending on the method used. Section 5 focuses on the long term comparisons based on a decomposition of gross surplus in three components - depreciation cost, opportunity/financial cost and net

\footnotetext{
1 "Evaluation of the capital value, investments and capital costs in the fishery sector, N ${ }^{\circ}$ Fish/2005/03" and "Programme de Biodiversité ANR -IFB 2005, Chaloupe - CHAngement gLObal, dynamiqUe de la biodiversité marine exploitée et viabilité des PEcheries“.
} 
profit. As expected, the gaps between the two regimes for capital valuation are discussed based on the common sample.

\section{Case Study and Representativeness of Samples}

The assessment of economic performance is addressed in the case of the professional Brittany fishing fleet during the year 2003. The fishing industry in Brittany represented $40 \%$ of the industry at national level excluding the French Mediterranean fleets. The number of fishing units in the population located on the Atlantic Coast in the Channel and the North Sea was 3935 [10], including 2707 boats under 12 metres long. If $47 \%$ of boats in the population use active gear, the number in Brittany is even higher (53\%).

Table 1. The Brittany professional fishing fleet, year 2003

\begin{tabular}{|c|c|c|c|c|c|c|}
\hline & \multicolumn{3}{|c|}{ Brittany } & \multicolumn{3}{c|}{ France } \\
\hline $\begin{array}{c}\text { Fleet } \\
\text { segments }\end{array}$ & Active gear & Passive gear & Total & Active gear & Passive gear & Total \\
\hline$<12 \mathrm{~m}$ & $47 \%$ & $35 \%$ & $39 \%$ & 917 & 1790 & 2707 \\
\hline$>12 \mathrm{~m}$ & $42 \%$ & $44 \%$ & $42 \%$ & 939 & 289 & 1228 \\
\hline Total & $45 \%$ & $36 \%$ & $40 \%$ & 1856 & 2079 & 3935 \\
\hline
\end{tabular}

Source: Ifremer (2004)

The commercial fishing fleet in Brittany is geographically located in 14 maritime districts. 58\% of the population is situated along the South Breton coast - from Vannes to Douarnenez, while $42 \%$ lies in Northern Brittany - from Camaret to Saint- Malo. The highest concentration of boats is in Le Guilvinec (21\%), amongst these is a large number of offshore fleets, whereas coastal fleets are dominant in other marine districts.

Figure 1. Distribution of the commercial fishing fleet in Brittany, year 2003

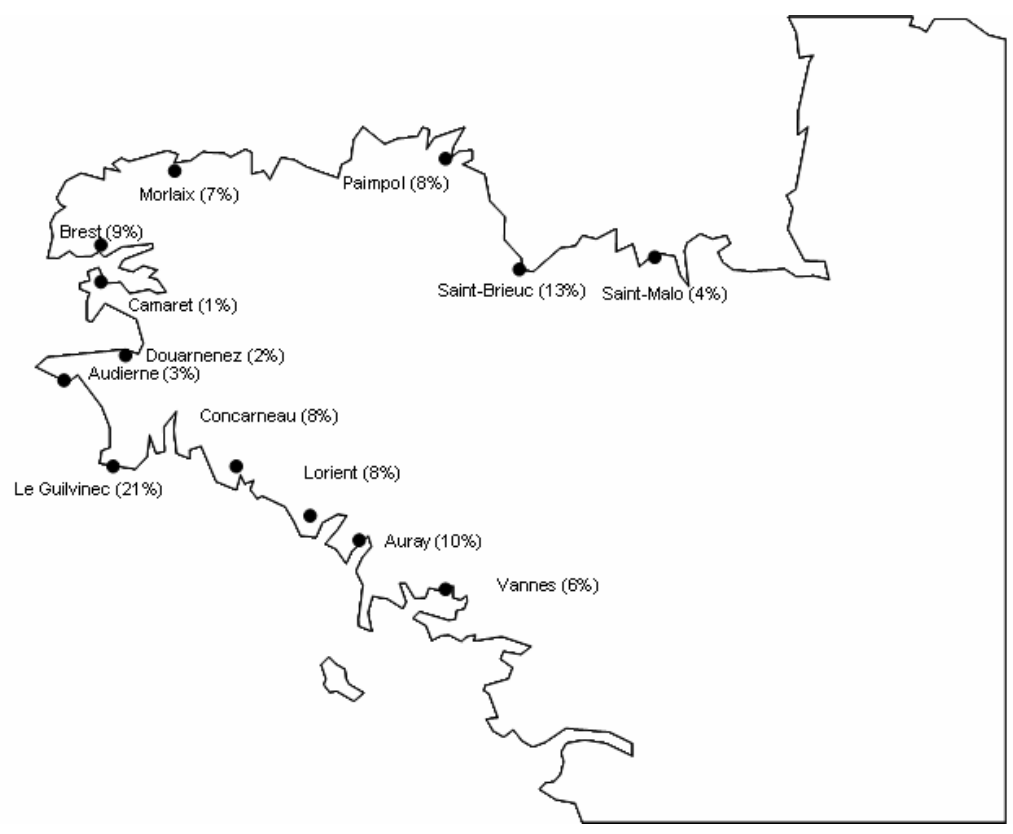


As the comparative analysis is focused on both short term and long term economic performance, indicators are separated according to both approaches. In the short term, the analysis requires landings value and operating costs to assess gross surplus. In the long term, fixed capital depreciation and financial costs are included. Consequently, due to additional information on capital components, the size of the common sample is smaller than the sample used on the previous occasion [4]. This sample contains 77 boats which represents a global sampling rate of $5 \%$ of the corresponding population (1575 boats).

Table 2. Common sample, year 2003

\begin{tabular}{|l|c|c|c|}
\hline Fleet segments & Active gear & Passive gear & Total \\
\hline$<12 \mathrm{~m}$ & 24 & 24 & 48 \\
\hline$>12 \mathrm{~m}$ & 18 & 11 & 29 \\
\hline All units & 42 & 35 & 77 \\
\hline
\end{tabular}

At the sample level, boats less than 12 metres long, using mainly active gear and boats over 12 metres long using passive gear are over-represented in comparison to the fleet structure in Brittany. However, fishing vessels under 12 metres long using passive gear are underrepresented in the sample.

Figure 2. Comparative structure of fleet in Brittany and common sample by length class and main gear

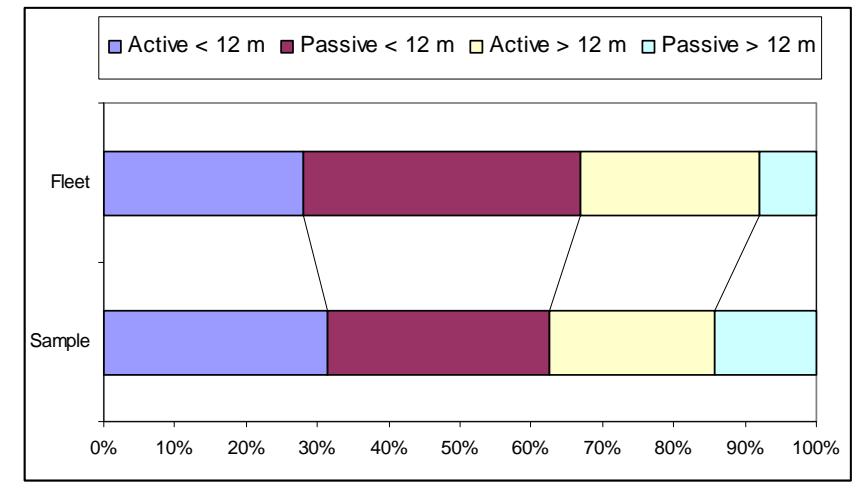

Because of the restricted number of units in the common sample, only two classes in terms of length will be considered in the following analysis. The lifetime is slightly longer for boats under 12 metres long - 22 years on average. Standard deviation is given in brackets.

Table 3. Technical parameters, common sample, year 2003

\begin{tabular}{|c|c|c|c|c|c|c|}
\hline Fleet segments & $\begin{array}{l}\text { Number } \\
\text { of boats }\end{array}$ & $\begin{array}{c}\text { Age in } 2003 \\
\text { (years) }\end{array}$ & $\begin{array}{l}\text { Length } \\
(\mathrm{m})\end{array}$ & $\begin{array}{c}\text { Tonnage } \\
(\mathrm{tjb})\end{array}$ & \begin{tabular}{|c|} 
Engine power \\
$(\mathrm{kw})$
\end{tabular} & Crew \\
\hline All units & 77 & $\begin{array}{r}21.3 \\
2.4\end{array}$ & $\begin{array}{r}11.9 \\
2.9\end{array}$ & $\begin{array}{r}19.6 \\
1.5\end{array}$ & $\begin{array}{r}167 \\
\quad 1.0\end{array}$ & $\begin{array}{l}2.9 \\
1.6\end{array}$ \\
\hline$<12 \mathrm{~m}$ & 48 & $\begin{array}{r}22.0 \\
2.4\end{array}$ & $\begin{array}{l}9.3 \\
5.7\end{array}$ & $\begin{array}{l}8.8 \\
2.4\end{array}$ & $\begin{array}{l}107 \\
1.8\end{array}$ & $\begin{array}{l}1.8 \\
2.0\end{array}$ \\
\hline$>12 \mathrm{~m}$ & 29 & $\begin{array}{r}20.2 \\
2.3\end{array}$ & $\begin{array}{r}16.1 \\
4.6\end{array}$ & $\begin{array}{r}37.4 \\
2.2\end{array}$ & $\begin{array}{r}267 \\
1.7\end{array}$ & $\begin{array}{l}4.5 \\
2.9\end{array}$ \\
\hline
\end{tabular}

The following sections are devoted to short and long term economic performance and results are derived from the common sample according to length class. Table 4 defines current indicators in the short and long-term used in this paper. 
Table 4. Definition of economic and financial indicators

\begin{tabular}{|r|l|l|}
\hline \multicolumn{2}{|c|}{ Short term economic performance } \\
\hline Gross revenue & $=$ & Landings value \\
\hline Operating costs & $=$ & Fuel, gear, maintenance, repairs \\
\hline Labour costs & $=$ & Crew payments \\
\hline Value added & $=$ & Gross revenue - Operating costs \\
\hline Gross surplus & $=$ & Gross revenue - Operating costs- Labour costs \\
\hline Long term economic performance \\
\hline Full equity profit & $=$ & Gross surplus - depreciation costs \\
\hline Net profit & $=$ & Full equity profit - opportunity cost \\
\hline Return on capital & $=$ & Full equity profit / capital value \\
\hline
\end{tabular}

\section{Short-Run Economic Performance.}

First of all, economic performance is assessed in the short-term. Indicators are : landings value, value-added and gross-surplus. Both sources of information, namely surveys and bookkeeping are used simultaneously for the same set of vessels. Differences between them are then discussed.

Figure 3. Gap between estimations of landings value, value added and gross surplus for the entire common sample (bookkeepping - field survey, as a \% of field survey)

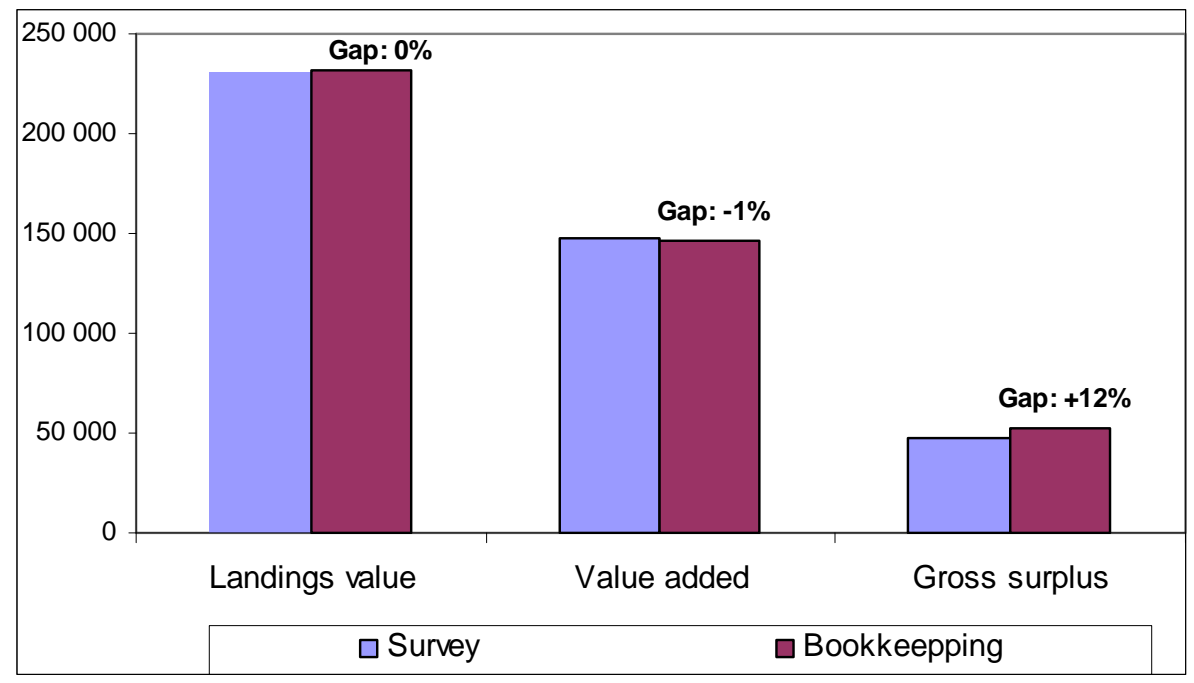

Figure 3 depicts comparisons between bookkeeping and survey data. Preliminary results for the whole common sample indicate a very close correspondence in terms of average landings value and value-added. The accounting framework is based primarily on turnover, assimilating gross revenue and other operating products. This value is actually identical to the survey data collected by questionnaire. In terms of value-added, the result is hardly any lower for bookkeeping (-1\%). Common items have been included in the intermediate costs such as landing costs, fuel, ice, food, gear, maintenance and repairs, insurance and miscellaneous costs. In the opposite case, a significant difference is observed for gross surplus, the gap being estimated to $12 \%$ in favour of bookkeeping compared to survey. In the bookkeeping database, the premium for the skipper-owner is assimilated to labour costs. If we consider this item as a wage component (as is done in bookkeeping documents), the gap represents only $+3.2 \%$. However, owner premium has to be treated as a revenue for the entrepreneur and consequently has to be separated from labour costs.

A contrast between boats less than 12 metres and over 12 metres in length was identified with a similar comparison made on the 2001 year [4]. In the case of units under 12 metres long, bookkeeping data provides results slightly higher than field survey for landings value 
and value-added - respectively $+2 \%$ and $+1 \%$. On the other hand, the gap is seriously significant with regard to gross surplus. It is estimated to 39\% (taking owner premium included with gross surplus). As already explained in the previous paper [4], differences in gross surplus are rooted in institutional problems, specifically for the smaller fishing vessels. Indeed, the share system in the artisanal sector is applied to boats above 12 metres long and, more randomly, for small units. Frequently labour costs correspond to social costs in bookkeeping databases when the skipper-owner is the only member of the crew. In the opposite case, survey reports [10] assume a normal labour revenue for fishermen even if only one member is aboard.

Figure 4. Gap between estimations of landings value, value added and gross surplus subsample under 12 metres long (bookkeepping - field survey, as a \% of field survey)

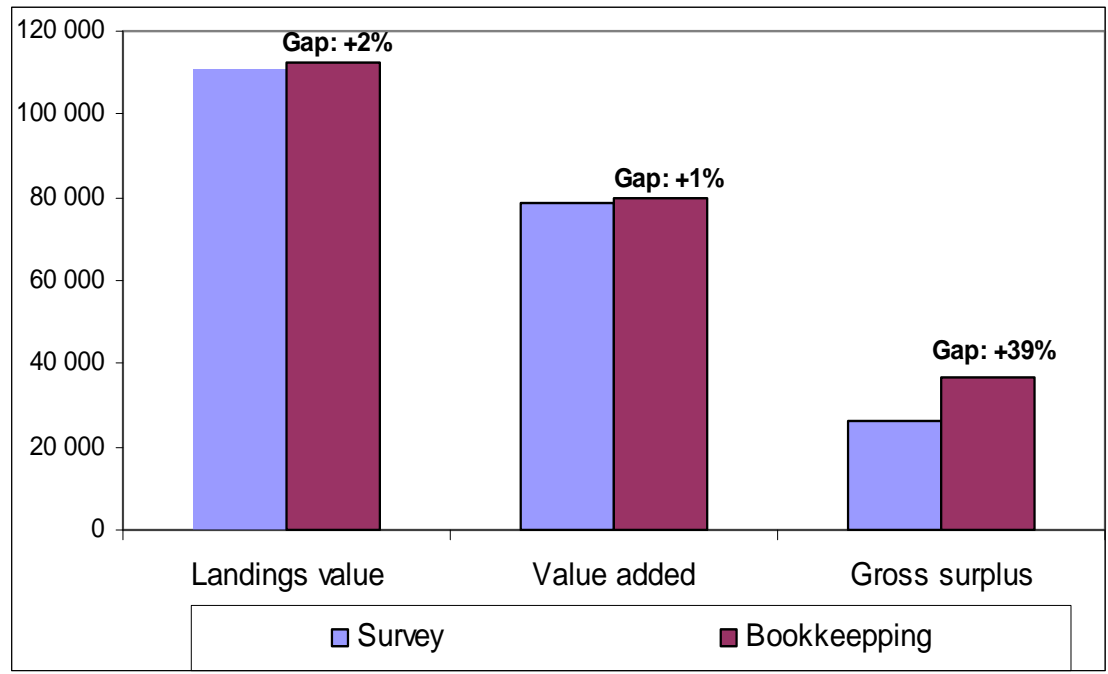

Results are very close for boats over 12 metres long, assuming owner premium as capital revenue. In this case, the gap for gross surplus is cut to $-2 \%$ but would be nearer $-13 \%$ if this item was considered as a labour cost. According to the retained assumption of the boatowner premiums, short-run economic performance in terms of gross surplus can be greatly biased. For instance, gross surplus for boats over 12 metres long increases by $13 \%$ (80k euros instead of $71 \mathrm{k}$ euros) if the owner premium is not considered as a wage component, from bookkeeping source.

Figure 5. Gap between estimations of landings value, value added and gross surplus subsample above 12 metres long (bookkeepping - field survey, as a \% of field survey)

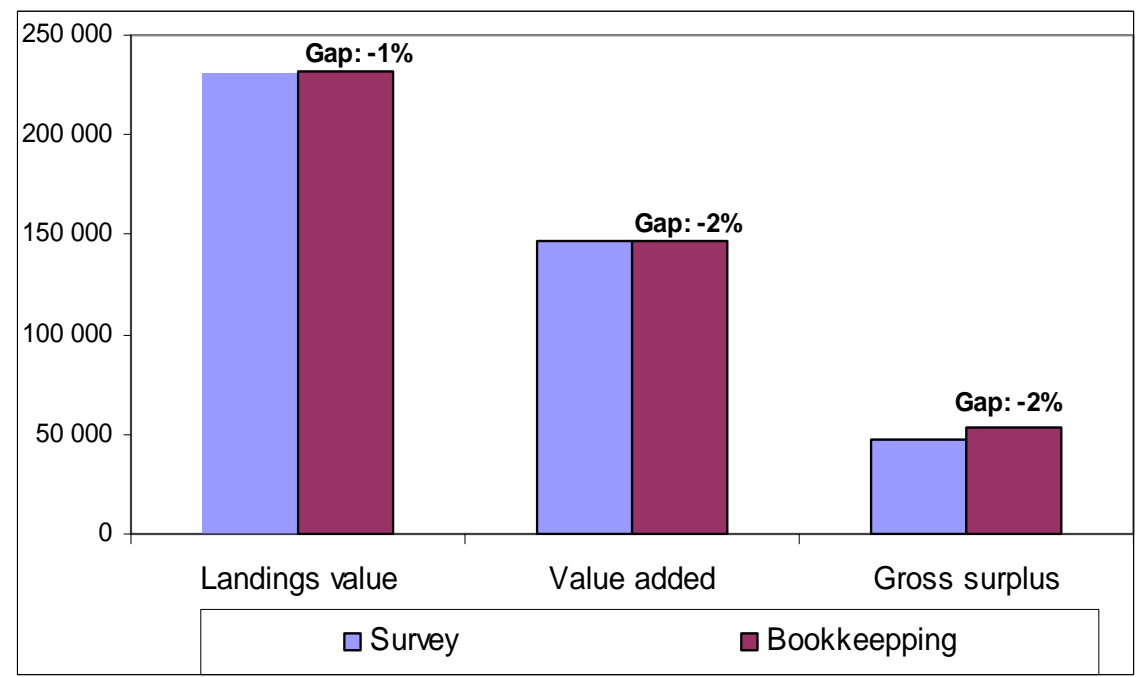


The examination of running costs show positive gaps for " maintenance/repairs » and « insurance ». In accounting registration, capital components (like fishing gear) can be considered as running expenses whereas their characteristics are comparable with investments. These two types of cost represent $12-17 \%$ of total running costs $(8-11 \%$ for maintenance/repairs and $4-6 \%$ for insurance). Significant negative gaps (up to 10\%) are identified for « ice, food, gear », «labour costs » and « miscellaneous costs ». «Ice, food and gear » are higher in surveys. A potential explanation is related to a different classification of gears and maintenance/repairs expenses, according to bookkeeping and surveys. Differences in labour costs concern only small boats $(-17 \%)$ due to a non generalized share system in bookkeeping. Concerning miscellaneous net costs, the gap is significant only for the biggest vessels (-15\%).

Figure 6. Gap between estimations of types of costs for the entire common sample (bookkeepping - field survey, as a \% of field survey)

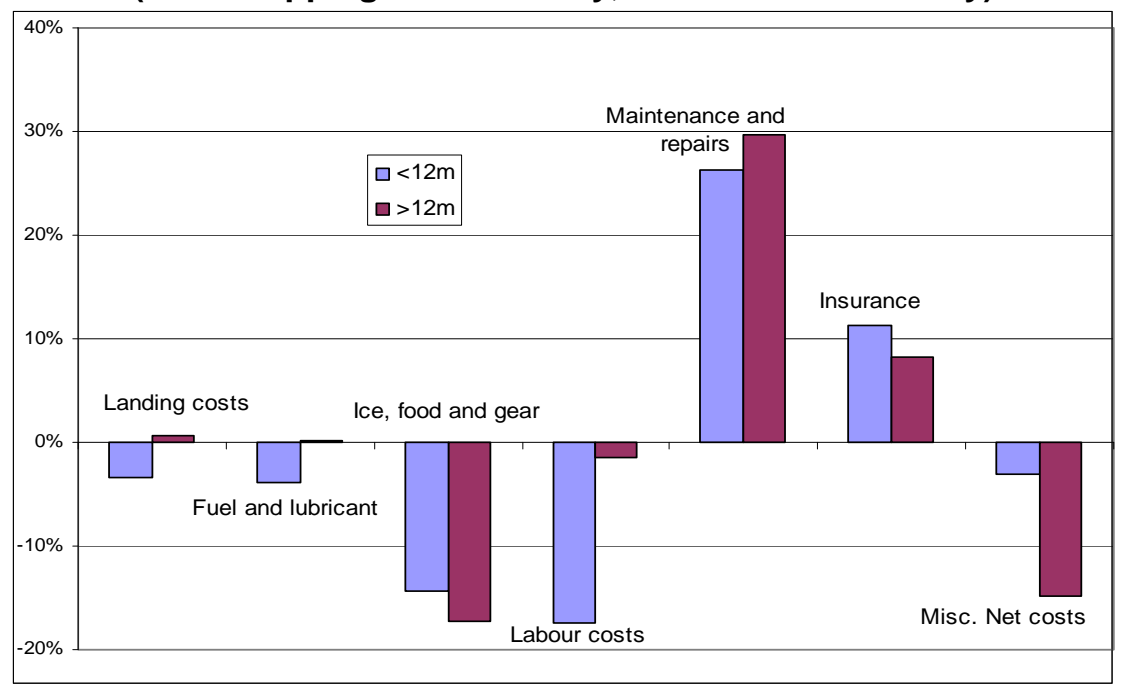

In the short-run, economic indicators are based purely on production and running costs. If trends can be made easily from landings value, value-added and gross surplus, no indication is supplied on capital and investment dynamics. For instance, a better revenue for the entrepreneur does not mean an increase in the fishing capital stock. Capital valuation is therefore required to produce economic indicators in the long-run. Consequently the final objective consists of the decomposition of gross surplus according to the capital costs. The following section is devoted to a methodological description of capital valuation from which capital costs can be derived.

\section{Capital Valuation and Capital Costs in Fisheries}

This section includes economic information on capital value. Two directions are suggested to investigate long-run economic performance on the basis of the common sample. The bookkeeping database is an initial source, but is strongly influenced by fiscal considerations. In parallel, capital and fleet surveys allow modelling for capital price estimation.

On the one hand, fiscal regime is used by private fishing companies to calculate the annual cost of tangible assets, considered either as a unique component (fishing vessel as a whole), or decomposed in relation to the main components (hull, engine, electronics, other equipment). In the first perspective, depreciation costs are computed according to the fiscal regime permitted by the national tax laws. On the other hand, estimated values of capital 
(including non physical assets) can be derived from models taking account of fishing fleet characteristics. In certain circumstances, both these ways can be consistent.

\section{Fiscal Regime for Fishing Fleets in France}

Capital value, derived from the bookkeeping database, is recorded through book value (or historical prices) and net worth. Book value and net worth can be seen on the balance sheet as fixed assets. The latter results from the difference between the former and the sum of fiscal depreciation, defined as a flow in the profit and loss account.

Book value can be used as the starting point for evaluating fishing capital and is defined as historical value (price paid for the assets at the time of its acquisition, either new or second hand). Contrastingly, net worth does not correspond to economic value due to fiscal rules, allowing a 6-year lifetime for depreciation. Consequently, fishing companies benefit from a capital gain when they sell tangible assets on the second hand market. Thus, the special regime permitted by law, produced a financial leverage effect, giving incentives to skipperowners to reinvest their capital gain in fisheries.

As happens in most private companies, the value of fishing capital is included in the balance sheets provided by the Regional Economic Observatory. Hence, bookkeeping data on capital illustrates the opening and closing stocks of capital assets. Historic cost (or acquisition price) of capital is depreciated following a specific depreciation rule.

The French fiscal regulations are based on two depreciation methods - the linear and the digressive system. If the former is considered as the norm, the latter is admitted only to a few capital assets. Fishing companies can use a digressive function for new and second-hand vessels. From a fiscal perspective, a fishing vessel's lifetime is a minimum of 6 years. Under these conditions, a company can fully depreciate its vessel in 6 years, whereas the estimated economic lifetime usually exceeds 20 years.

As indicated in the following table showing fiscal computation for capital depreciation according to the French regulatory basis, a coefficient is applied to the linear rate for obtaining the appropriate digressive rate [3]. New and second-hand vessels bought before $01 / 01 / 2001$ could be depreciated by applying a $33.33 \%$ rate or $37.5 \%$ a year (respectively $29.17 \%$ and $33.75 \%$ since 01/01/2001).

Table 5. Special tax law applied to fishing fleets in France

\begin{tabular}{|l|l|r|r|r|r|}
\hline \multirow{2}{*}{ Life time } & \multirow{2}{*}{ Linear rate } & \multicolumn{2}{|c|}{ Before $01 / 01 / 2001$} & \multicolumn{2}{c|}{ Since 01/01/2001 } \\
\cline { 3 - 6 } & & Coefficient & Digressive rate & Coefficient & Digressive rate \\
\hline 3 & 33.33 & 1.5 & 50 & 1.25 & 41.67 \\
\hline 4 & 25 & 1.5 & 37.5 & 1.25 & 31.25 \\
\hline 5 & 20 & 2 & 40 & 1.75 & 35 \\
\hline 6 & 16.67 & 2 & 33.33 & 1.75 & 29.17 \\
\hline $62 / 3$ & 15 & 2.5 & 37.5 & 2.25 & 33.75 \\
\hline 8 & 12.5 & 2.5 & 31.25 & 2.25 & 28.13 \\
\hline 10 & 10 & 2.5 & 25 & 2.25 & 22.5 \\
\hline 12 & 8.33 & 2.5 & 20.83 & 2.25 & 18.75 \\
\hline 15 & 6.67 & 2.5 & 16.67 & 2.25 & 15 \\
\hline 20 & 5 & 2.5 & 12.5 & 2.25 & 11.25 \\
\hline
\end{tabular}

Source : Mémento pratique Francis Lefebvre (p165) - Fiscal - 2003

If the digressive rule for depreciation in fisheries is not fully appropriate, the adoption of this method in the case of the French, can be explained in terms of investment incentives in the sector. As described in the OECD manual on capital [14], « ...geometric depreciation will not therefore be appropriate for assets that require an increasing amount of maintenance...or that consume more energy and other inputs with age ». 
The main conclusion due to fiscal lifetime for depreciating fishing vessels (6 years) is to generate a high capital gain for sellers. Every time a fishing vessel is sold, capital gain results from the difference between the amount of second-hand value and the worth value (or depreciated historic price). Consequently, capital gain is equal to second hand value if the fishing capital is fully depreciated from a fiscal point of view (worth being equal to zero). In this case, the French fiscal regulation considers capital gain as a short-term gain and is liable for income tax, close to $60 \%$. According to a study describing financial consequences of fiscal regime in fisheries [2], the amount of tax burden on capital gain is the reason why prices on the second-hand fishing vessel market have reached very high levels in midnineties.

For instance - consider a capital gain of $150,000 €$ linked to a fishing vessel sold on the French second-hand market. If the skipper-owner reinvested $100,000 €$ in a fishing vessel (new or second-hand), a fraction of the capital gain $(50,000 €)$ would be taxed at $60 \%$ in the current fiscal year, and the other part $(100,000 €)$ would be spread over the next 7 fiscal years. A distinction must be made between short-term and long-term capital gain (table 6). The former represents cumulated fiscal depreciation (B or $F$ ) and the latter $(G)$ is the difference between capital gain (E) and short-term capital gain (F).

Table 6. Short term and long term capital gain

\begin{tabular}{|c|c|c|c|c|c|c|}
\hline $\begin{array}{c}\text { Historical } \\
\text { price }(A)\end{array}$ & $\begin{array}{c}\text { Cumulated } \\
\text { fiscal } \\
\text { depreciation } \\
(B)\end{array}$ & $\begin{array}{c}\text { Residual value } \\
(\mathrm{C})=(\mathrm{A})-(\mathrm{B})\end{array}$ & $\begin{array}{c}\text { Second } \\
\text { hand price } \\
(\mathrm{D})\end{array}$ & $\begin{array}{c}\text { Capital gain } \\
(\mathrm{E})=(\mathrm{D})- \\
(\mathrm{C})\end{array}$ & $\begin{array}{c}\text { Short term } \\
\text { capital } \\
\text { gain }^{(1)} \\
(\mathrm{F})=(\mathrm{B})\end{array}$ & $\begin{array}{c}\text { Long term } \\
\text { capital gain } \\
(\mathrm{G})=(\mathrm{E})-(\mathrm{F})\end{array}$ \\
\hline 100 & 33 & 67 & 120 & 53 & 33 & 20 \\
\hline 100 & 66 & 34 & 120 & 86 & 66 & 20 \\
\hline 100 & 100 & 0 & 120 & 120 & 100 & 20 \\
\hline
\end{tabular}

Source: Anonym., 2005.

The French fiscal law taxes short-term capital gain at $59.09 \%$ (maximum income tax at $48.09 \%$ and social deductions at $11 \%$ ). The law taxes long-term capital gain at $27 \%$ (a flat rate of tax at $16 \%$ and social deductions at $11 \%$ ). If a capital gain is expected, meaning a second-hand price higher than residual value, we systematically observe a higher part of the short-term capital gain compared to the long-term capital gain, considering the application of a digressive rate by $33 \%$ (table 6). A fishing vessel sold for $120 €$ only one year after the purchase period, for an initial investment of $100 €$, will be subject to the upper tax limit (59.09\%) on $62 \%$ of capital gain (33€) and the lower limit (27\%) on $38 \%$ of the capital gain $(20 €)$. On the other hand, for a sale on the second-hand market two years later, $77 \%$ of capital gain (66€) is taxed at $59.09 \%$. Usually, fishing vessels are sold once the capital is fully depreciated, like the third example in the table. Hence, taxes concern essentially shortterm capital gain for which the level of taxes is the highest. For this reason, the French authorities decided on a tax avoidance regime, implemented through the Fishing Guidance Act adopted in 1997, following the «fishing crisis » in 1993-1994. This special measure should have ended in 2003, but has actually been extended. According to this measure, the fishing vessel owners can benefit from partial tax exemption on capital gain (short-term capital gain). They have to reinvest fully the amount of sold asset in the fisheries sector over a period of 18 months following transaction. In this case, capital gain is spread over the following 7 fiscal years, whereas capital gain is taxed at $60 \%$ during the last fiscal year if there is no reinvestment.

\subsection{Economic Valuation}

In a recent report on capital valuation in Europe [1], an econometric model was elaborated to measure capital stock for the French fishing fleets. An economic valuation has been carried out using the hedonic approach. In this conceptual context, the price of a vessel is influenced by its characteristics. Skipper-owners are expected to value their production means 
according to their attributes (physical and non-physical assets). Hedonic prices are consequently a function of the attributes. This approach is recommended when several physical (age, length, engine power, tonnage) and non-physical attributes (fishing rights) are included as explanatory variables in a single model [12].

Based on a time series on new and second-hand vessel prices, regression models have been tested to measure gross capital stock at a given time and estimate a depreciation function of the vessel price according to its age [7]. In the French context, the availability of data on acquisition price and vessel characteristics allows us to use the hedonic approach [8]. Eventually, the net capital stock estimated could be different from the market value of the vessel which also contains the implicit value of the fishing rights specifically in the French context [9].

The equation is estimated using semi-logarithmic functional forms where the dependant variable is the logarithm of the price measured in the real term (taking account of the rate of inflation).

\section{Figure 7. Equation}

$$
\log \left(Y_{i}\right)=\alpha+\beta K+\lambda_{N} I_{n e w}+\lambda t+\sum_{T=1985}^{2003} \delta_{T} I_{T}+\varepsilon_{i}
$$

Where

$Y_{i}=$ Market price of the vessel $\mathrm{i}$

$\mathrm{t}=$ Age of the vessel $i$ the transaction year

$\mathrm{T}=$ Transaction year

$\mathrm{K}=$ Technical characteristics (length, deviation from GRT and from kW, Type of hull)

$I_{\text {new }}=1$ if the vessel was New, 0 else

$I_{T}=1$ if the transaction occurs the year $\mathrm{T}, 0$ else

Two datasets are required. The first one is the database of the IFREMER Fishery Statistics. IFREMER conducts yearly surveys on a sample of 800 vessels (around 600 vessels from the Atlantic Coast) to collect individual data on not only costs and earnings, but also on capital and employment devoted to the commercial fishing activity. The « economic sample » made available is composed of 3500 individual data collected between 2000 and 2004 . The vessel owners are questioned on their costs and earnings in detail and also on the features of their fishing vessel(s) and its components (hull, engine, gear and winches, electronics and storage) and their related prices (historical, replacement, insurance or market value). A complementary database exists at IFREMER of around $70 \%$ of the second-hand market transactions which have taken place from 1985 to 2003 along the French coast. This data comes from the Affaires Maritimes districts and is collected with the support of the French Ministry of Fisheries. The date and the price of each transaction are available. This dataset contains around 4600 observations from 1985 to 2004 which were used for an assessment of the second-hand vessel prices market using the hedonic method. Results on depreciation method and the value of intangible assets in the French sector are deduced for this model [7]. 
Table 7. Results from the economic valuation model

\begin{tabular}{|l|c|c|l|c|c|}
\hline & Parameter & $\mathrm{t}$ & & Parameter & $\mathrm{t}$ \\
\hline $\mathbf{R}^{\mathbf{2}}$ & $\mathbf{0 . 7 9 7 1}$ & & & & \\
\hline Intercept & 5.74 & $<00$ & Class_year 1987 & & \\
\hline Length & 2.45 & $<00$ & Class_year 1988 & 0.11 & 0.0167 \\
\hline Dev_GRT & 0.14 & $<00$ & Class_year 1989 & 0.10 & 0.0267 \\
\hline Dev-KW & 0.11 & $<00$ & Class_year 1990 & 0.20 & $<00$ \\
\hline Fleet_1 trawler & & & Class_year 1991 & 0.31 & $<00$ \\
\hline Fleet_2 Seiner & -0.15 & 0.1105 & Class_year 1992 & 0.17 & 0.0007 \\
\hline Fleet_3 Dredger & -0.06 & 0.0262 & Class_year 1993 & 0.05 & 0.3282 \\
\hline Fleet_4 Passive & -0.23 & $<00$ & Class_year 1994 & 0.07 & 0.1498 \\
\hline Fleet_5 Other & -0.48 & $<00$ & Class_year 1995 & 0.10 & 0.0397 \\
\hline Wood & 0.12 & $<00$ & Class_year 1996 & 0.14 & 0.0027 \\
\hline Plastic & 0.25 & $<00$ & Class_year 1997 & 0.26 & $<00$ \\
\hline Metal & & & Class_year 1998 & 0.49 & $<00$ \\
\hline Other & -0.25 & 0.1598 & Class_year 1999 & 0.68 & $<00$ \\
\hline Dummy_new & 0.13 & $<00$ & Class_year 2000 & 0.73 & $<00$ \\
\hline Age & -0.03 & $<00$ & Class_year 2001 & 0.96 & $<00$ \\
\hline Class_year 1985 & -0.12 & 0.0302 & Class_year 2002 & 0.99 & $<00$ \\
\hline Class_year 1986 & -0.03 & 0.5095 & Class_year 2003 & 1.11 & $<00$ \\
\hline
\end{tabular}

The year seems to have an influence on the vessel price in the second-hand market. Guyader [8] considered in their hedonic model that the year captured the change in the implicit price of fishing rights. These rights were freely distributed to the fishermen but seem to have shadow values that are contained in the market price when there is a transaction. In the main, one of the points of interest in this model is the measurement of the influence of the age of the vessel on its price in the market.

The depreciation function is basically a geometric depreciation [14] where the market value is declining at a constant rate in each period. The depreciation rate is $16 \%$ the first year (from the year of construction to year 1) and $4 \%$ per year after.

Compared to other studies in the fishing sector [13], the depreciation for the first year is comparable. However, the constant rate for the following years is much lower. Moreover, some questions are raised about the consistency of a constant rate over the period as investigated in [13].

\section{The Pros and Cons of Both Methods for Capital Valuation}

In the recent report carried out on capital valuation and investments [11], the fiscal valuation approach is considered as a micro approach and economic valuation as a macro approach. The former method is presented in the OECD manual [14] through the Perpetual Inventory Method (PIM). Different annual depreciation rates are then defined for hull, engine, electronics and other equipment. The latter requires a model to estimate capital value from which the annual cost is derived.

These two main approaches (fiscal/micro and economic valuation/macro) offer a spectrum of alternative value for capital, depending on a global (the vessel as a whole) or detailed, (hull, engine, electronics, other equipment) description of assets, linear or digressive functions, and annual rates permitted.

A compromise solution between fiscal and economic valuation is presented in [6]. Calculations were based on data collection by questionnaire and aimed at measuring 
economic performance of fisheries exploited by fleets located in Brittany, France. Digressive rates, coming from the French fiscal regime were used to estimate linear depreciation rates in concordance with the average lifetime of physical assets. This 'mixed' method was used to compute the annual costs of physical fishing capital, separating hull and engine [6].

An economic survey of fishermen showed an average life span of vessel of 28 years (none answering was inferior to 20 years). Consequently, economic depreciation could not be based on pure fiscal considerations (assuming a minimum lifetime of 6 years for vessels). Eventually, lifetime was approximated at 25 years for hull and 10 years for engine. A full linear function, including annual costs for hull and engine, was tested with a rate of $10 \%$ for hull and $25 \%$ for engine (figure 8 ).

Figure 8. Theoretical evolution of physical fishing capital costs

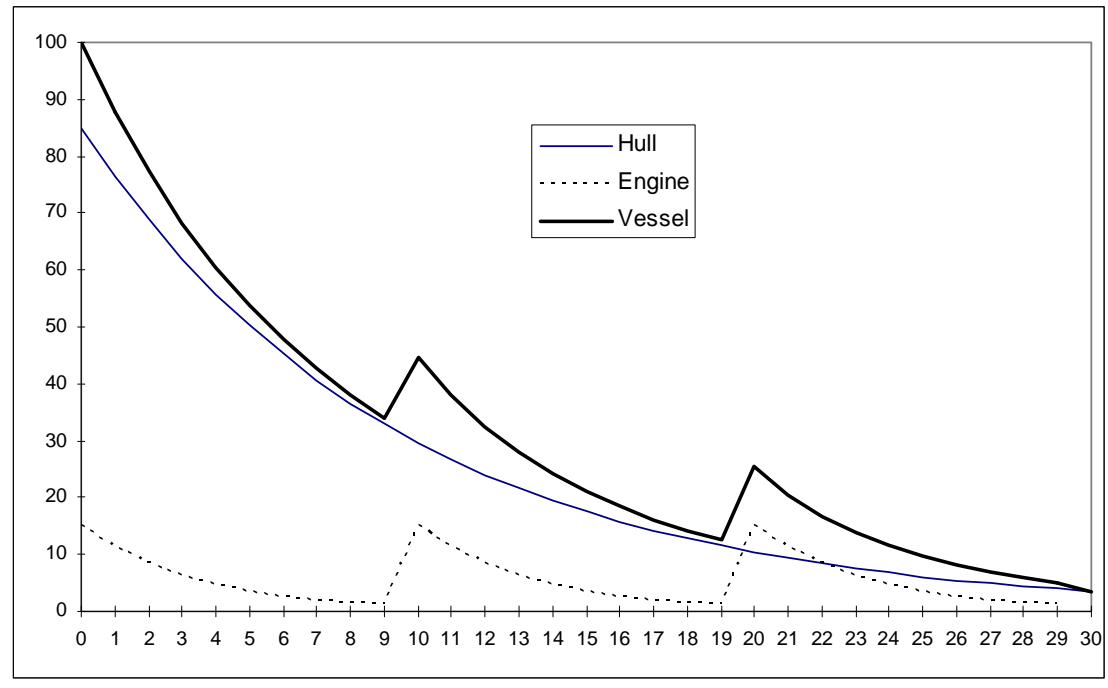

Source: Boncoeur et al., 1996

If we compare theoretical results with those from fiscal and economic (hedonic) value, we see three different paths for a single vessel sold at $100 €$. From the French fiscal method, residual value is close to zero in ten years. As explained above, capital gain (in the case of a sale on the second-hand market) is composed exclusively of short-term capital gain for which taxes are at $59.09 \%$. Economic value still gives a residual price of $60 \%$ at the same period (after ten years). Indeed, annual cost for depreciation represents $16 \%$ in $t=1$, and $4 \%$ a year from $t=2$. Both methods of capital valuation used in this paper can be considered as the lower (fiscal) and the upper (economic value) limits (figure 9). 
Figure 9. Evolution of fiscal and economic values of physical fishing capital costs

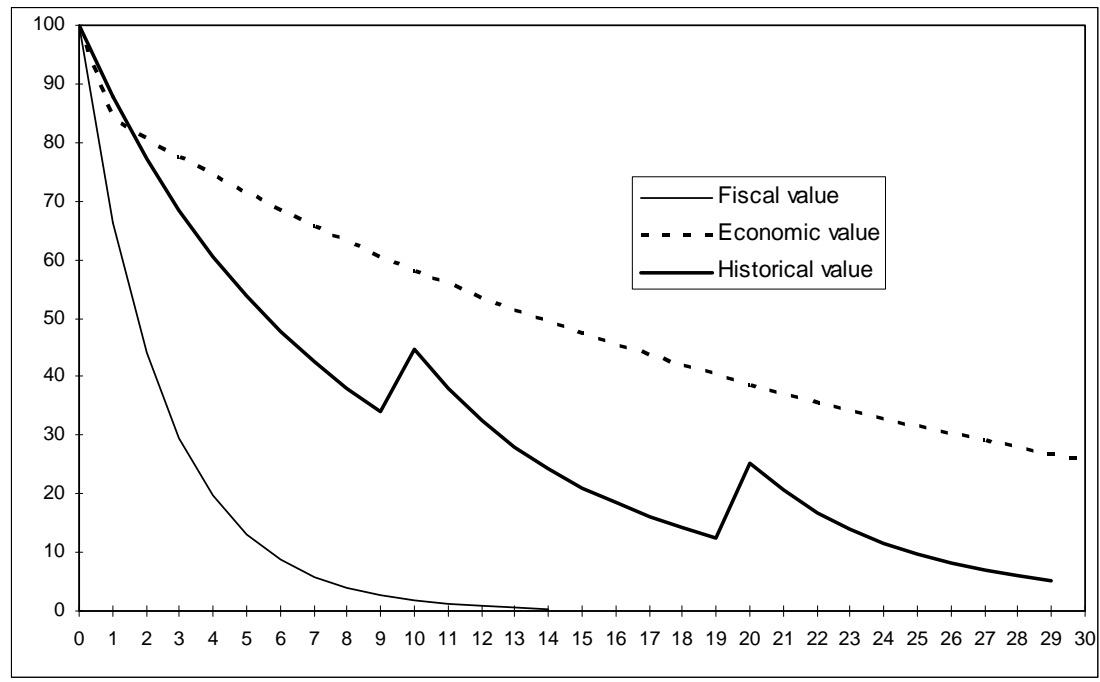

Fiscal consideration is mainly oriented towards a short-term perspective, giving incentives to skipper-owners to reinvest in the sector. Influenced by all characteristics, econometric value is expected to reflect physical value (hull, engine, electronics) and non-physical value (shadow price for the fishing rights). In this context, long-term performance indicators will be strongly impacted depending on the method used.

\section{Long-Run Economic Performance}

Average results are based on gross capital value, annual depreciation and net capital value (figure 10). Differences between model value (computed from the hedonic price model) and bookkeeping (book value) are expressed as a \% of bookkeeping. For the entire sample, estimations of gross capital are very close (a gap of $2 \%$ is observed). However, results are under-estimated with the model for smaller boats. At the opposite scale, capital value is higher (9\%) with the model compared to book values for vessels above 12 metres long. As a consequence of alternative depreciation function, the annual cost of capital in 2003 is significantly weaker (by $78 \%$ ) with the model. Finally, residual value is higher by $62 \%$ using model value (the gap reaches $96 \%$ for bigger boats).

Figure 10. Gap between estimations of gross capital value (a), depreciation (b), net capital value (c), (model value - bookkeepping, as a \% of bookkeepping)

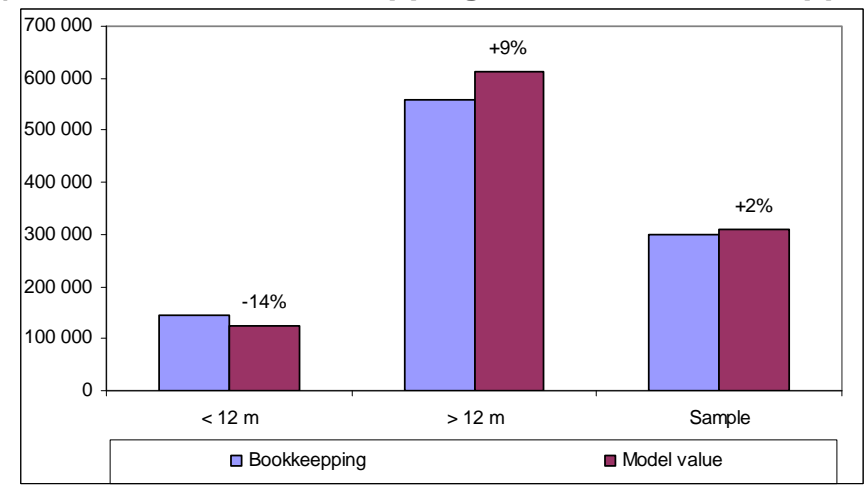

(a) 


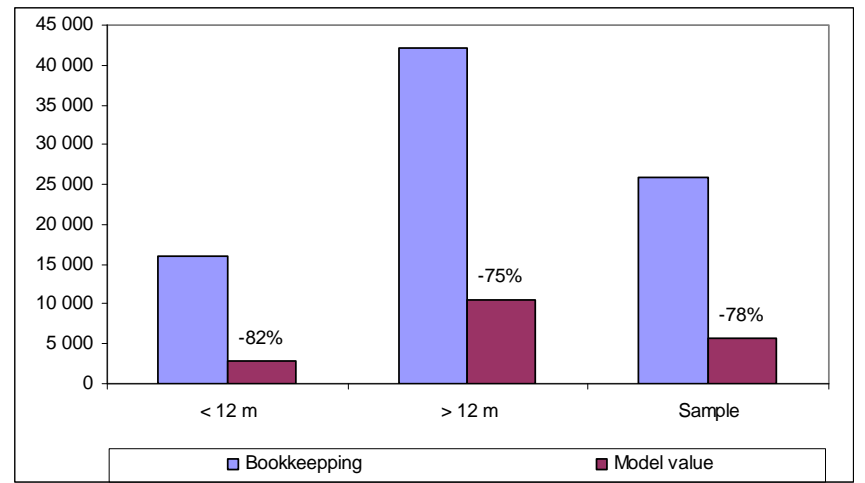

(b)

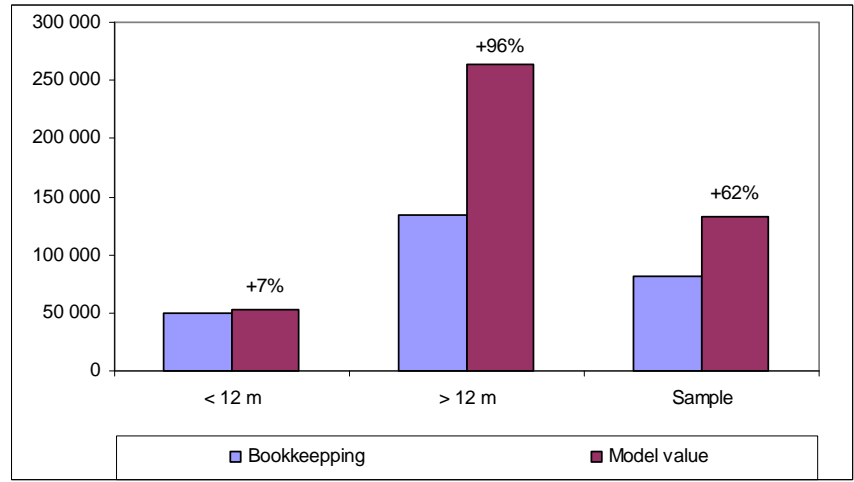

(c)

Table 8 compares long-term economic performance, based on full equity profit (gross surplus minus depreciation cost) and net profit (full equity profit minus opportunity cost). Differences are analysed between model value and bookkeeping, as a $\%$ of bookkeeping. If performances are computed from surveys and model value for capital, scores are higher by $66 \%$ in comparison with bookkeeping. The gap rises by $107 \%$ for boats above 12 metres long. The main explanation for this comes from the method used to compute the annual cost of capital (depreciation). Opportunity costs and financial costs are not so different. The former is estimated in model value applying a rate of $2.3 \%$ to insurance value, this rate corresponding to the real interest rate (difference between the rate for Government Bonds and the inflation rate). The latter represents, in the bookkeeping database, the annual financial cost in 2003.

Table 8. Costs of capital and net profit, year 2003

\begin{tabular}{|l|l|r|r|r|r|c|}
\hline \multicolumn{2}{|l|}{ Fleet segments } & $\begin{array}{c}\text { Depreciation } \\
\text { costs }\end{array}$ & $\begin{array}{c}\text { Full equity } \\
\text { profit }\end{array}$ & $\begin{array}{c}\text { Opportunity } \\
\text { costs / } \\
\text { interests }\end{array}$ & $\begin{array}{c}\text { Net } \\
\text { Profit }\end{array}$ & $\begin{array}{c}\text { Gap on net } \\
\text { profit }\end{array}$ \\
\hline \multirow{2}{*}{ All units } & Model value & 5785 & 41326 & 5643 & 35683 & \multirow{2}{*}{$+66 \%$} \\
\cline { 2 - 6 } & Bookkeepping & 25917 & 27047 & 5575 & 21472 & \\
\hline$<12 \mathrm{~m}$ & Model value & 2917 & 23383 & 2509 & 20874 & \multirow{2}{*}{$+24 \%$} \\
\cline { 2 - 6 } & Bookkeepping & 16090 & 20465 & 3599 & 16866 & \multirow{2}{*}{$+107 \%$} \\
\hline \multirow{2}{*}{$>12 \mathrm{~m}$} & Model value & 10532 & 71024 & 10830 & 60194 & \\
\cline { 2 - 6 } & Bookkeepping & 42183 & 37943 & 8847 & 29096 & \\
\hline
\end{tabular}

Decomposing gross surplus in three components shows the consequences of different depreciation regimes (figure 11). With the model value, net profit absorbs $76 \%$ of gross surplus, while only $41 \%$ is affected to skipper-owner as net profit with bookkeeping. In return, half of gross surplus represents an annual depreciation cost in the accounting framework of $12 \%$ with the model. Gaps are slightly expanded in the case of vessels above 12 metres. $53 \%$ of gross surplus is considered as depreciation. Consequences concern investment capacity inside the fisheries sector. An economic perspective of long-term performance (as shown with the model value and surveys) describes the entrepreneur profit [5], including part of the rent, as fishing rights are not tradeable (another part of this rent being attached to labour revenue with the share system). In this context, profitability of invested capital can appear better than results given from the accounting system. 
Figure 11. Decomposition of gross surplus for the entire common sample (a), sub-sample under 12 metres long (b), sub-sample above 12 metres long (c)

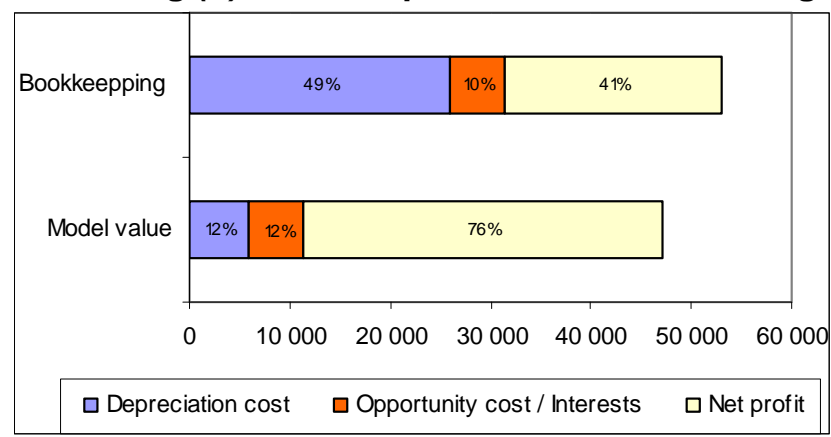

(a)

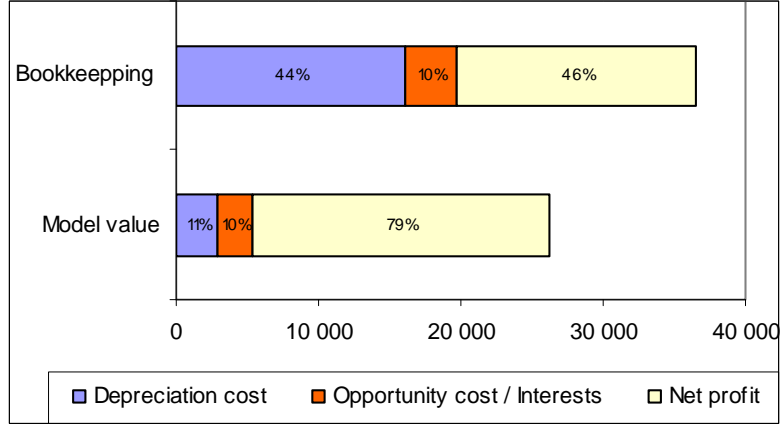

(b)

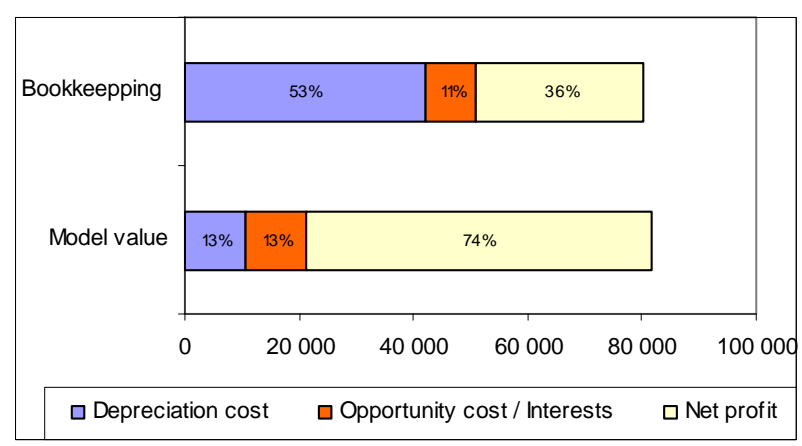

(c)

\section{Discussion}

In this paper, we have explained the ins and outs of the French fiscal regime and the hedonic price model to value fishing capital. The former system supplies fishermen with a dispensation regime, so that fishing companies can use the geometric system for both new and second-hand vessels. In these conditions, a company can fully depreciate its vessel in 6 years, whereas estimated economic lifetime is usually over 20 years. With an economic perspective based on the hedonic price models, physical variables such as vessel size, fleet, type of hull and year of purchase explain variables to estimate gross capital value. Hence a depreciation rate of $16 \%$ is applied for the first year and a constant rate of $4 \%$ the following years.

In the short-term, several attempts have been made to compare bookkeeping and surveys [4]. Analysing the gaps between both economic data collection methods leads to a mutual validation. It must be emphasised that results from bookkeeping can be considered irrelevant in measuring short-term performance of fishing boats in certain circumstances. This is the case with small boats where «non-wage labour is a major input » [5]. It is then recommended that labour and owner revenues be separated, in terms of wages and miscellaneous premiums, for instance to consider a full wage for a single fisherman (as in surveys) or to reallocate crew payments according to various positions for crew members (as a skipper-owner or a worker).

The problem is more critical in the long-term when invested capital is used to compare the performance of fishing vessels. On the one hand, the fiscal regime in fisheries plays a crucial role in investment dynamics. The French fiscal framework produces strong incentives to reinvest capital gain in the sector. In this way, net profit computed with bookkeeping seems meagre in comparison to scores obtained with the model value and surveys. 
In addition, another problem must be addressed in the valuation of capital in the fisheries industry. Basically, capital has to be divided into two parts: physical assets and non-physical assets (fishing rights). For instance, fiscal depreciation is based on physical and non-physical value in the case of second-hand vessels (if individual fishing rights do not exist). In this respect, the hedonic price theory aims to estimate both elements of capital, which is not the case with book value.

Long-run performance indicators have to be clearly defined to avoid misinterpretation on capital costs (mainly depreciation function) and net profit. If capital was considered here exclusively as stock, a possible extension of this research would be an assessment of capital flows to analyse capital and investment dynamics.

\section{References}

[1] Anonym. Economic Performance of Selected European fishing fleets. Annual report 2005, EC Contract Economic Assessment of European Fisheries. 2006; 306 p.

[2] Anonym. Transmission et financement des entreprises de pêche. Etude réalisée par l'Ofimer, le From Bretagne, le Crédit Mutuel de Bretagne, les cabinets Fidal et PriceWatersCoopers. 2005; 49p.

[3] Anonym. Mémento pratique Francis Lefebvre. Fiscal. Editions Francis Lefebvre. 2003; 1630p.

[4] Boncoeur J, Daurès F, Guyader O, Martin A, Le Floc'h P, Thébaud O. Comparing bookkeeping and field survey methods for assessing fishing fleets economic performance: $A$ case study of Brittany fishing fleet (France). IIFET 2004 Proceedings. 2004.

[5] Boncoeur J, Coglan L, Le Gallic B, Pascoe S. On the (ir)relevance of rates of return measures of economic performance to small boats. Fisheries Research 2000; 49:105-115.

[6] Boncoeur J, Bailly $D$, Le Floc'h $P$. Enquête économique sur la pêche côtière professionnelle en Bretagne Nord et dans le golfe Normand-Breton. Université de Bretagne Occidentale, Cedem. 1996; 128p.

[7] Daurès F, Bihel J, Guyader O, Le Floc'h P, Roudaut N, Brigaudeau C, Thébaud O, Jézéquel $\mathrm{M}$. Estimating capital value and depreciation of fishing fleets: Application to French fisheries. IIFET 2006 Portsmouth Proceedings. 2006.

[8] Guyader O, Le Pellec L, Pons E, Daurès F. Analysis of vessel prices on second-hand markets (Atlantic area - France). XVth EAFE conference, Brest. 2003.

[9] Guyader $O$, Berthou $P$, Daurès $F$, Jézéquel $M$, Thébaud $O$. Marché des navires d'occasion et coût d'accès à la ressource : Application à la Bretagne. Communication à l'Atelier International « Régulation de l'accès aux ressources marines vivantes dans la zone côtière : expériences internationales et perspectives pour la Bretagne, Plouzané. 2006.

[10] IFREMER. Synthèse des flottilles de pêche 2004 - Flotte de Mer du Nord - Manche Atlantique. Système d'Informations Halieutiques. 2005; 54p.

[11] Irepa. Evaluation of the capital value, investments and capital costs in the fisheries sector, $n^{\circ}$ Fish/2005/03, final report. 2006.

[12] Kirkley, J. E. and D. Squires. A limited information approach for determining capital stock and investment in a fishery, Fishery Bulletin. 1998; Vol. 86:2: 339-349.

[13] Lee, Bun S. Measurement of Capital Depreciation within the Japanese fleet, The Review of Economics and Statistics. 1978; 60:2:225-237.

[14] OCDE. Measuring capital - OECD Manuel. Measurement of capital stocks, consumption of fixed capital services. 2001; 131p. 
[15] Whitmarsh D., Lames C., Pickering H., Neiland A., The profitability of marine commercial fisheries: a review of economic information needs with particular reference to the UK, Marine Policy. 2000;24:257-263. 